\title{
On-reserve forest fuel management under the Federal Mountain Pine Beetle Program and Mountain Pine Beetle Initiative
}

\author{
Brian Peter ${ }^{1, *}$, Matthew Milovanovic ${ }^{2}$, Nello Cataldo $^{1}$ and Maureen Scott ${ }^{1}$
}

\begin{abstract}
We report here on the achievements and program costs for on-reserve forest fuel management under the Federal Mountain Pine Beetle Program and Mountain Pine Beetle Initiative. From 2002-2010 these two programs helped 88 First Nations bands and organizations plan and carry out forest fuel management on reserves across the BC interior. In all cases, the first step in treating hazardous fuels under these programs was the development of professionally prepared fuel management plans and prescriptions. After plans were in place, approximately 2700 hectares were treated through various combinations of thinning, pruning, fuel reduction and fuel removal. Over 8000 hazard trees were removed and approximately $15 \mathrm{~km}$ of fuel breaks were established. Costs to implement fuel treatments varied widely based on a number of factors including size of the area treated, initial stand conditions and density, terrain, treatment details, and site-specific values requiring protection.
\end{abstract}

Keywords: wildfire, fuel treatment, FireSmart, wildland-urban interface, mountain pine beetle

\section{RÉSUMÉ}

Nous faisons état des progrès réalisésréalisations et des coûts des travaux de gestion des combustibles forestiers dans des réserves amérindiennes des combustibles forestiers réalisés selon leen vertu du Programme fédéral sur le dendroctone du pin ponderosa du gouvernement fédéral et le Programme sur le dendroctone du pin. Entre 2002 et 2010, ces deux programmes ont permis à 88 bandes et organismes des Premières Nations de planifier et deffectuerntreprendre des travaux de gestion des combustibles forestiers dans des réserves de l'Iintérieur de la Colombie-Britannique. Dans le cas de toutes lles casinterventions, la première étape de la gestion despour gérer les combustibles dangereux en marge de ces programmes consistait à faire préparer par des professionnels a été ldes planse développement de façon professionnelle d’un plan de gestion des combustibles et des prescriptions afférentesrequises. Une fois Sur la base de ces plans, complétée la mise en place des plans, près de 2700 hectares ont été traitées traités selon avec différentes combinaisons déclaircie, délagage, et de coupes de réduction et d'enlèvement des du combustibles forestiers. Plus de 8000 arbres dangereux ont été enlevés et lon a créé environ $1515 \mathrm{~km}$ de coupe-feu ont été créés. Les coûts cesde réalisation des traitements des combustibles ont fluctué grandement en fonction de certains facteurs comme la taille de la superficie à traiter, les conditions initiales du peuplement et sa densité, le terrain, la spécificité des traitements et les valeurs spécifiques du au site devant êtreà protégerées.

Mots clés : feu de forêt, traitement des combustibles, FireSmart, zones périurbaines, dendroctone du pin ponderosa

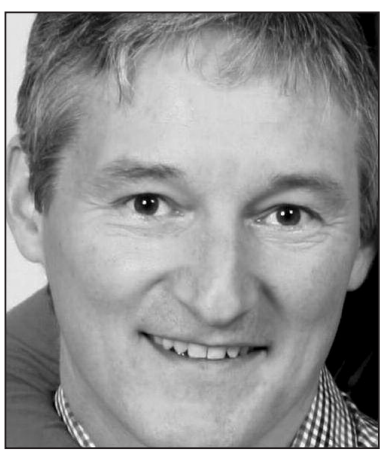

Brian Peter

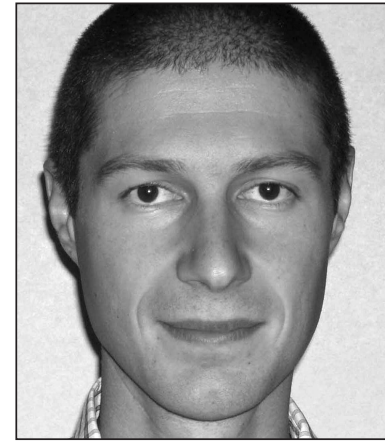

Matthew Milovanovic

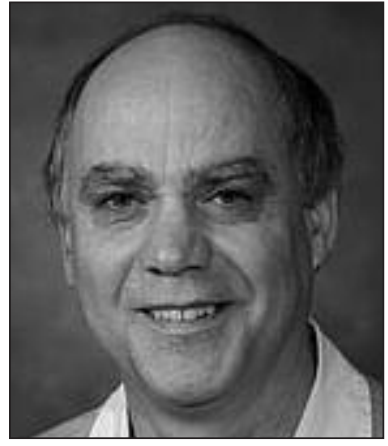

Nello Cataldo

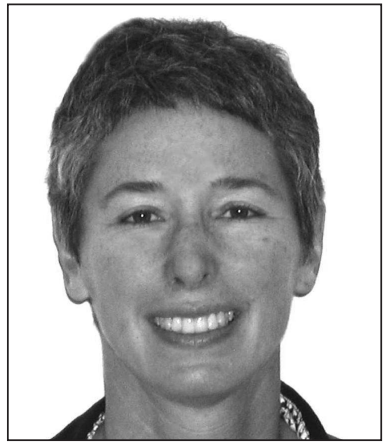

Maureen Scott

\footnotetext{
${ }^{1}$ Natural Resources Canada, Canadian Forest Service, Pacific Forestry Centre, Victoria, BC.

${ }^{2}$ Formerly with Natural Resources Canada, Canadian Forest Service, Pacific Forestry Centre, Victoria, BC.

*Corresponding author, email: brian.peter@canada.ca
} 


\section{Introduction}

In British Columbia, risks to communities from wildfire came into sharp focus following the damaging fires of 2003, and the subsequent provincial review (Filmon 2004) that highlighted the issue of fuel buildup in wildland-urban interface (WUI) areas. Dead pine left in the wake of the recent mountain pine beetle (MPB) epidemic further contributed to concerns over WUI risks. The Government of Canada responded to the MPB epidemic with the Mountain Pine Beetle Initiative (MPBI) from 2002-2006, and the subsequent Mountain Pine Beetle Program (MPBP) from 2007-2010. Combined federal expenditures under these two programs amounted to \$227 million (for additional details see Wilson 2004, CFS 2016). One aspect of these programs was the provision of funding for fuel management and hazard tree removal in post-infested areas. Under these programs some fuel treatments and prescribed fires in National Parks were funded, and several municipalities and school districts received funding to remove hazard trees. However, the majority of fuel treatment work under these two programs involved 88 First Nations bands and organizations that carried out forest fuel management planning and treatments on reserves across the $\mathrm{BC}$ interior.

Fuel treatments aim to reduce the wildfire threat by breaking up the continuity of fuels in a way that may reduce fire intensity or make fires easier to suppress. Although fuel treatments do not eliminate wildfire risks to WUI areas, they are one recognized way that risks can be reduced, especially when combined with other "FireSmart" strategies such as those that improve structural fire resistance. Periodic maintenance of fuel treatments is also required for ongoing effectiveness (Partners in Protection 2003, Agee and Skinner 2005).

In $\mathrm{BC}$, responsibility for fuel treatments in WUI areas is complex due to the mix of municipal, provincial, First Nations and individual private landowners that have jurisdiction over the forests that affect WUI risks. The Government of BC in partnership with the Union of BC Municipalities and the First Nations Emergency Services Society takes a lead role in encouraging, facilitating and funding fuel treatment proj-

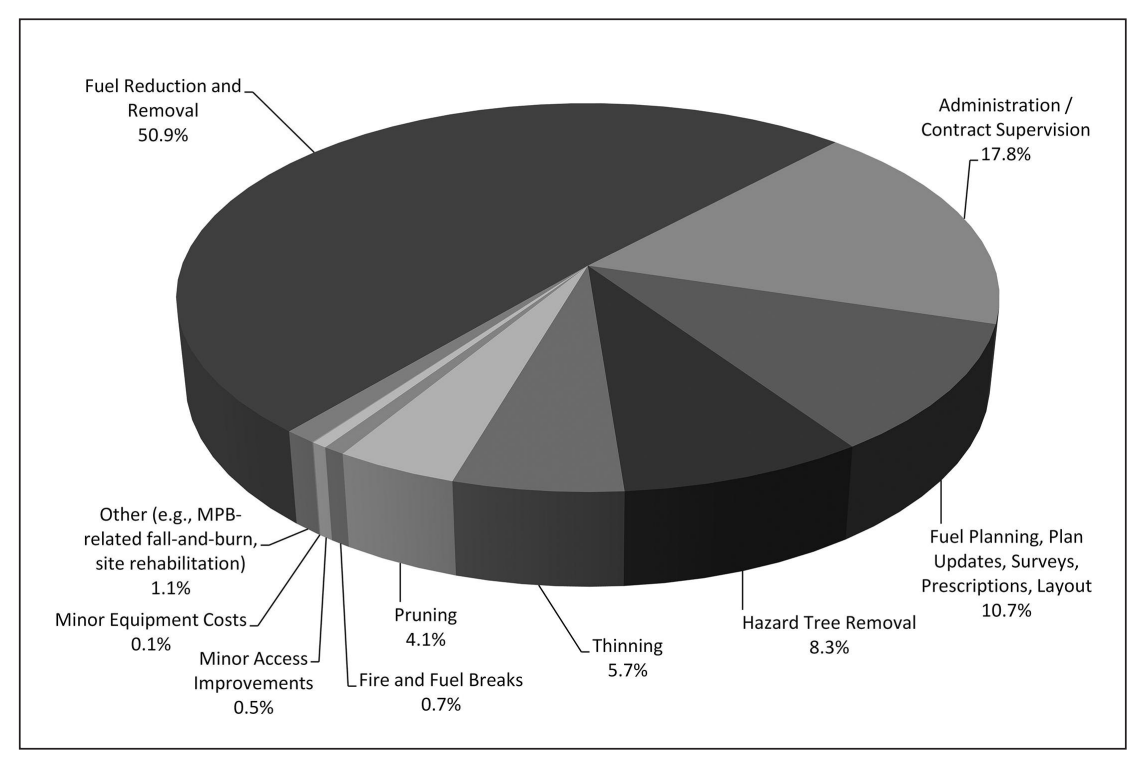

Fig. 1. First Nations Forest Fuel Management expenditures under MPBI/MPBP ects on municipal and provincial Crown land through the Strategic Wildfire Prevention Initiative. A recent Forest Practices Board report (BCFPB 2015) noted, among other things, the limited support at present for fuel treatments on both private and reserve lands, and that little information exists on what treatments typically should cost. While some information on costs is available, much of this is in the "gray literature" or is from outside Canada (e.g., Hartsough et al. 2008, Gawalko 2012, Hvenegaard 2012). For this reason, we felt it would be useful to report on the information we have on MPBI/MPBP programs for on-reserve fuel treatments in BC, what was achieved, program costs, and some of the apparent factors affecting costs. We have not assessed the overall economics of these treatments (i.e., comparing the discounted present value of expected treatment benefits versus treatment costs), but simply want to report on a substantial program of fuel treatment work that was done to address on-reserve wildfire risks in $\mathrm{BC}$.

\section{Program Activities and Costs}

In all cases, the first step in treating hazardous fuels under these programs was the development of professionally prepared fuel management plans and prescriptions that identified treatment needs based on current FireSmart principles. After plans were in place, approximately 2700 hectares were treated through various combinations of thinning, pruning and surface fuel reduction (i.e., reduction or removal of thinning/pruning slash or other understory fuels). Over 8000 hazard trees were removed and approximately $15 \mathrm{~km}$ of fuel breaks were established ( $30 \mathrm{~m}$ to $50 \mathrm{~m}$ wide removal of surface fuels, including $5 \mathrm{~m}$ on each side cleared down to mineral soil). Some MPB-related treatments such as falling and burning infested trees or site rehabilitation were also carried out as part of the forest fuel management programs, though these amounted to just over $1 \%$ of program expenditures. The total aggregate cost of these projects was $\$ 11.7$ million. Some recipients contributed in-kind costs or expenditures that were not covered by federal funding, though details of these were not consistently available so are not included.

Costs to treat hazardous fuels included: 1) fuel management plan creation, 2) plan updates, 3) the treatments themselves, and 4) administration (e.g., issuing contracts, invoicing, meetings, inspections, monitoring, documentation and hiring qualified professionals to oversee treatments). In a few cases, minor road access improvements were required before treatments could occur. Fig. 1 illustrates the break-down of costs for the program by category. Note that in many cases, fuel management plans covered areas larger than were treated, and in a few cases, plans considered forest management issues not related to fuel management (e.g., postMPB rehabilitation). In a few instances, fuel management planning was done but no further work was completed under the programs. 


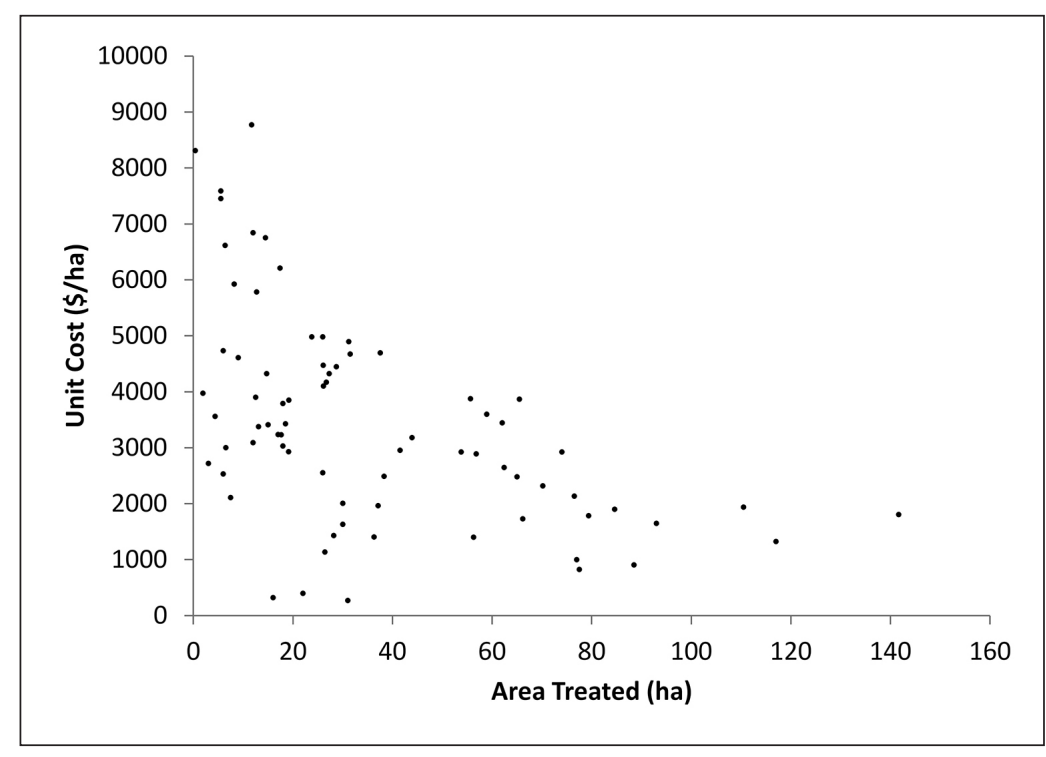

Fig. 2. Cost per hectare for thinning, pruning, fuel reduction and removal by area treated for each recipient.

Costs per hectare for thinning, pruning, fuel reduction and removal (the most widely applied treatments) for each recipient were determined and were plotted against the total area treated (Fig. 2). This illustrates that the highest costs generally occurred when comparatively small areas were treated. This is not surprising since fixed costs (e.g., mobilization) will typically be lower on a per hectare basis when they are spread over larger areas. Contractors and crews may also gain experience and find efficiencies as they progress through larger treatment areas, particularly as fuel treatments remain a relatively new type of stand management. Overall, the average cost for these treatments was $\$ 2613$ per hectare, although this only includes the cost of crews carrying out the work, and does not include administration, planning, and layout. It was not possible to include these in per hectare cost estimates as they sometimes related to multiple treatments or activities. Most treatments (96.5\% of the area treated) cost less than $\$ 5000$ per hectare, although the two most expensive treatments cost over $\$ 8000$ per hectare. The second most expensive of these ( $\$ 8310$ per hectare) was the smallest area treated under the program ( 0.4 hectares). The three largest areas treated (110 hectares to 140 hectares) cost between $\$ 1300$ and $\$ 2000$ per hectare.

Some comparatively small areas also had comparatively small per hectare costs (Fig. 2). Other treatment details obviously affect costs, particularly as a range of treatment options are available and initial stand conditions may vary widely. For example, the least expensive treatment ( $\$ 268$ per hectare) occurred in low-density ponderosa pine (Pinus ponderosa Dougl. ex P. \& C. Laws.) on gentle terrain, and appears to have only involved light biomass removal. At the other end of the spectrum, the most expensive treatment was $\$ 8774$ per hectare, and high costs here were due to high fuel density and in part to the presence of archaeologically sensitive sites within the treatment area, which led to the need for careful hand-falling of MPB-killed trees.

\section{Conclusion}

Further analysis would be needed to determine specific relationships with other drivers of costs. However, these results do illustrate, for this particular program (involving sites of up to 140 hectares), the average and the range of costs to support fuel treatments across a broad geographic area in British Columbia. Costs can vary widely and appear to depend on a number of factors including the size of the area treated, initial stand conditions and density, terrain, treatment details, and sitespecific values requiring protection. These programs for on-reserve fuel treatments ended with the expiry of the MPBP in 2010, and while substantial progress was made in addressing risks in the aftermath of the MPB outbreak, fuel management will continue to require attention on WUI reserves and in other WUI communities in BC.

\section{References}

Agee, J.K. and C.N. Skinner. 2005. Basic principles of forest fuel reduction treatments. Forest Ecol. Manag. 211: 83-96.

BCFPB. 2015. Fuel management in the wildland urban interface Update. Special Investigation Report FPB/SIR/43, BC Forest Practices Board, Victoria BC. 34 p. https://www.bcfpb.ca/sites/default/ files/SIR43-Fuel-Management-Update.pdf [accessed 15 July 2016]

CFS. 2016. Mountain Pine Beetle Program (2007-2010) [online]. Canadian Forest Service, Natural Resources Canada, Ottawa, ON. http://www.nrcan.gc.ca/forests/fire-insects-disturbances/topinsects/13399 [accessed 15 July 2016]

Filmon, G. 2004. Firestorm 2003 provincial review. Province of British Columbia, Victoria, BC. 100 p. http://www2.gov.bc.ca/assets/ gov/farming-natural-resources-and-industry/forestry/wildfiremanagement/governance/bcws_firestormreport_2003.pdf [accessed 15 July 2016]

Gawalko, L. 2012. British Columbia's Strategic Wildfire Prevention Initiative Program, costs and variables. Presentation at Wildland Fire Canada 2012 - Kananaskis, Alberta. https://www.ualberta.ca/ wildfire/2012/PDFs/Lyle\%20Gawalko.pdf [accessed 15 July 2016]

Hartsough, B.R., S. Abrams, R.J. Barbour, E.S. Drews, J.D. McIver, J.J. Moghaddas, D.W. Schwilk and S.L. Stephens. 2008. The economics of alternative fuel reduction treatments in western United States dry forests: Financial and policy implications from the National Fire and Fire Surrogate Study. Forest Policy Econ. 10: 344-354.

Hvenegaard, S. 2012. National wildland fuels management survey (revised), FPInnovations Contract Report CR-729(R). 46 p. http://wildfire.fpinnovations.ca/109/CR-729SHDNationalFuelsSurvey.pdf [accessed 15 July 2016]

Partners in Protection. 2003. FireSmart: Protecting Your Community from Wildfire [online]. Partners in Protection, Edmonton, AB. https://www.firesmartcanada.ca/resources-library/protecting-yourcommunity-from-wildfire [accessed 15 July 2016]

Wilson, B. 2004. An overview of the Mountain Pine Beetle Initiative. In: T.L. Shore, J.E. Brooks and J.E. Stone (eds). Mountain Pine Beetle Symposium: Challenges and Solutions, Kelowna, British Columbia, Canada, October 30-31, 2003. pp. 3-9. Natural Resources Canada, Canadian Forest Service, Pacific Forestry Centre, Victoria, British Columbia, Information Report BC-X-399. 